\title{
Lifestyle Relationships With Nutritional Status On Homless Children In the Safe House at Bandung 2017 (Generation Of Anti Narcotics and Criminality)
}

\author{
Sri Lestari Kartikawati ${ }^{1}$ \\ ${ }^{1}$ STIKES Bhakti Kencana Bandung Indonesia \\ sri.lestari.kartikawati@gmail.com
}

Sismeri Dona* ${ }^{2}$

${ }^{2}$ Sari Mulia Academy of Midwifery Banjarmasin Indonesia,

*sismeri_dona@akbidsarimulia.ac.id

$\operatorname{Rosa}^{1}$

${ }^{1}$ STIKES Bhakti Kencana Bandung Indonesia rosa@gmail.com

\begin{abstract}
Objective: to determine the corelation of lifestyle with nutritional status in street children in RPA Gank Bandung in 2017.

Methods: This research use analytic survey with cross sectional approach. Samples taken were 73 street children with sampling technique is simple random sampling Data collection by providing questionnaires with data processing using Chi Square with 95\% confidence level.

Results: The results of this study indicate that sleep habits are mostly $<6$ hours / day, more than half of the diet $<3$ times / day, smoking habits are mostly smoked, the habit of smell the glue more than half do not smell the glue, drinking alcohol more than half do not drink alcohol and drug use mostly do not use drugs. Nutritional status is less than half of normal, there is a significant relationship between sleeping habits with nutritional status, there is a significant relationship between diet with nutritional status, there is a significant relationship between smoking habit with nutritional status, there is a significant relationship between smell the glue habits with nutritional status, there was a significant relationship between alcohol consumption and nutritional status and there was a significant corelation between drug use and nutritional status and no relationship between sexual behavior and nutritional status.
\end{abstract}

Conclusion: there is a corelation life style with nutrition.

Keywords: Corelation, Lifestyle, Nutritional Status, Street Children.

\section{INTRODUCTION}

Street children are one of the most valuable assets to become Indonesia's future successors in the future. Most of the children's lives are on the streets to face the harsh street life, so it's not surprising that they have a slightly different attitude and morale than their age. For most people think that street children are quite unsettling road users. But they are just children who still do not understand anything, all they can do is how to find a bite of rice on the street in order to connect his life [1].

Street children, most of whom live on the streets, are simultaneously exposed to street 
environments. The apathetic, harsh and exploitative environment is almost always faced by street children [2]. But from the harsh street life, street children become strong and hard-willed individuals to move forward and improve their lives. Various kinds of stimulation from this street environment further form the street children's perception about learning situation [3]. But on the other hand street children can not be separated from the main problem of health problems.

Health problems that occur in street children is a condition of malnutrition due to eating patterns with irregular eating frequency. The state of malnutrition is one of the factors causing a person's easy to get infectious diseases, this is because the body's natural immune system is weakened. In addition, poor health status of street children can also lead to poor nutritional status [4].

If the nutritional status and health of street children are not met, it is feared that street children will become lost generation. According Soekirman economic problems Indonesia has been generating a generation with millions of children malnourished. If we do not watch out for quick and precise efforts then millions of undernourished children can be a lost generation, a generation with a lower intellectual power [5].

The child needs a balanced nutritional intake and adequate physical activity for optimal growth and height. school-age school children should have a good lifestyle in their infancy. To form a smart generation, many factors must be considered, including nutritional status and health. Nutrition is a nutrient needed by the body to grow and develop. Without adequate nutritional intake the child's growth will be disrupted [6]. Several factors that may affect the nutritional status include income, education, occupation, lifestyle, age, physical condition and infection [7].

Preliminary study conducted in RPA Gank obtained interview results of 5 adolescents, 4 teenagers say eat less than 3 times a day, and 1 teenager says eat 3 times a day. They say the night's sleep is always past 12 o'clock, all smoking, 2 people say sometimes smell the glue, 3 people say sometimes drink alcohol and nobody use drugs. The results of direct observation of 3 people with the condition of the body looked skinny and 2 people looked normal.

Lifestyle components studied by the study include resting habits, diet, activity patterns such as smoking, sleeping habits, drinking alcohol, drug use and sexual behavior [7]. Reviewing the above description, the authors are interested in conducting research on lifestyle relationships with nutritional status in street children in the House Protection Child Gank (Generation Anti Narcotics Crime) Bandung in 2017.

\section{METHODS}

This research is a correlation research with cross sectional, a research conducted at one time and one time, to find the relationship 
between independent variable (risk factor) with dependent variable (effect) [8]. The relationship in this study is between the variables of lifestyle (resting habits, eating patterns, smoking, smell the glue habits, drinking alcohol, drug use and sexual behavior) with nutritional status in street children in RPA Gank Bandung in 2017.

Population taken in this research is street children under the guidance of RPA Gank Bandung City recorded in May 2017 that as many as 200 people.

Sampling technique using simple random sampling. Respondents who are sampled are street children in RPA Gank with inclusion criteria of respondents who want to be sampled, that is respondents are ready to observe and respondents who can read and write. The exclusion criteria are: respondents who did not meet with the researcher at the time of the research, the respondents who were not present at the time of the research and the respondents who are not cooperative when done the research, respondents who always refused to answer when asked by the researcher.

\section{RESULTS}

Based on table 1, it is known that the habit of sleeping on street children in RPA Gank Bandung City mostly <6 hours / day $(89.0 \%)$ of 65 people and a small $>8$ hours / day $(1.4 \%)$ as much as 1 person. The pattern of eating on street children in RPA Gank Bandung more than half of $<3$ times / day
(64.4\%) of 47 people and less than half of $\geq 3$ times / day (35.6\%) of 26 people.

Smoking habits on street children in RPA Gank Bandung City mostly smoking $(98.6 \%)$ as many as 72 people and a small number of not smoking (1.4\%) as much as 1 person. Habit smell the glue on street children in RPA Gank Bandung more than half did not smell the glue (71.2\%) as many as 52 people and less than half smell the glue $(28.8 \%)$ as many as 21 people.

The habit of drinking alcohol on street children in RPA Gank Bandung more than half did not drink alcohol (72.6\%) as many as 53 people and less than half of drinking alcohol $(27.4 \%)$ of 20 people. Drug use in street children in RPA Gank Bandung City mostly did not use drugs (91.8\%) as many as 67 people and a small number of drugs $(8.2 \%)$ as many as 6 people. Severe sexual behavior $(64,4 \%)$ were 47 people and light sexual behavior $(35,6 \%)$ were 26 people.

Based on table 2 it is known that the nutritional status of street children in RPA Gank Bandung is less than half of normal (47.9\%) of 35 people and a small portion of obese $(8.2 \%)$ of 6 people.

From the calculation of Chi Square, it is known that $\mathrm{p}$-value $(0,045)$ is smaller than $\alpha$ $(0,05)$, so it can be concluded that there is a significant relationship between sleeping habits with nutritional status in street children in RPA Gank Kota Bandung.

From the calculation of Chi Square, it is known that $\mathrm{p}$-value $(0,000)$ is smaller than 
$\alpha(0,05)$, so it can be concluded that there is a significant relationship between diet with nutritional status in street children in RPA Gank Bandung.

From Chi Square calculation result, it is known that $\mathrm{p}$-value $(0,003)$ is smaller than $\alpha(0,05)$, so it can be concluded that there is a significant relationship between smoking habit and nutritional status in street children in RPA Gank Kota Bandung.

From the calculation of Chi Square, it is known that the value of p-value (0.002) is smaller than the value of $\alpha(0.05)$, so it can be concluded that there is a significant relationship between smell the glue habits with nutritional status in street children in RPA Gank Bandung.

From the calculation of Chi Square, it is known that p-value (0.004) is smaller than $\alpha(0,05)$, so it can be concluded that there is a significant relationship between drinking alcohol with nutritional status in street children in RPA Gank Kota Bandung.

From the calculation of Chi Square, it is known that $p$-value $(0.004)$ is smaller than $\alpha(0,05)$, so it can be concluded that there is a significant relationship between the use of drugs with nutritional status in street children in RPA Gank Kota Bandung. From the calculation of Chi Square, it is known that pvalue $(0.745)$ is bigger than $\alpha(0,05)$, so it can be concluded that there is no relationship between sexual behavior with nutritional status in street children in RPA Gank Kota Bandung.

Based on table 4, the candidate for multivariate is $p$-value $<0.25$. for variables of sleep habits, smoking habits and sexual behavior are not used as multivariate candidates due to $\mathrm{p}$-value $>0.25$.

Based on the table 5, the sequence of the highest that affect the nutritional status of the diet $(\mathrm{OR}=25.095)$ means that diet $>3$ times has a 25.095 times the chance of good nutrition compared to the pattern of eating $<3$ times. Drug use $(\mathrm{OR}=0.353)$ means that not using drugs has a 0.353 times the chance of good nutrition status compared with drug users. Drinking alcohol $(\mathrm{OR}=0.318)$ means that no drinking alcohol has a chance of 0.318 times a good nutritional status than those who drink alcohol. Habit smell the glue $(\mathrm{OR}=$ 0,295) means that no smell the glue opportunity 0.295 times the status of good nutrition than those who do not smell the glue. For more details can be seen in the following table: 
Table 1. Lifecycle Frequency Distribution of Lifestyle (Sleep Habits, Diet, Smoking, smell the glue, Drinking Alcohol, Drug Use and Sexual Behavior) on Street Children at RPA Gank Kota Bandung 2017

\begin{tabular}{|c|c|c|c|}
\hline No. & Lifestyle & Jumlah & Persentase \\
\hline \multirow[t]{4}{*}{1} & $\begin{array}{l}\text { Sleep Habits } \\
<6 \text { hour / day }\end{array}$ & 65 & 89,0 \\
\hline & 6-8 hour / day & 7 & 9,6 \\
\hline & $>8$ hour / day & 1 & 1,4 \\
\hline & $\begin{array}{r}\text { Total } \\
\end{array}$ & 73 & 100 \\
\hline \multirow[t]{3}{*}{2} & $\begin{array}{l}\text { Diet } \\
<3 \text { times / days }\end{array}$ & 47 & 64,4 \\
\hline & $\geq 3$ times / days & 26 & 35,6 \\
\hline & Total & 73 & 100 \\
\hline \multirow[t]{3}{*}{3} & $\begin{array}{l}\text { Smoking } \\
\text { Smoking }\end{array}$ & 72 & 98,6 \\
\hline & no smoking & 1 & 1,4 \\
\hline & Total & 73 & 100 \\
\hline \multirow[t]{3}{*}{4} & $\begin{array}{l}\text { smell the glue } \\
\text { yes }\end{array}$ & 21 & 28,8 \\
\hline & No & 52 & 71,2 \\
\hline & Total & 73 & 100 \\
\hline \multirow[t]{3}{*}{5} & $\begin{array}{l}\text { Drinking Alcohol } \\
\text { Drinking alcohol }\end{array}$ & 20 & 27,4 \\
\hline & No Drinking alcohol & 53 & 72,6 \\
\hline & Total & 73 & 100 \\
\hline \multirow[t]{2}{*}{6} & $\begin{array}{l}\text { Drug use } \\
\text { Drug use } \\
\text { No Drug use }\end{array}$ & $\begin{array}{l}6 \\
67\end{array}$ & $\begin{array}{r}8,2 \\
91,8\end{array}$ \\
\hline & $\begin{array}{r}\text { Total } \\
\end{array}$ & 73 & 100 \\
\hline \multirow[t]{3}{*}{7} & $\begin{array}{l}\text { Sexual Behavior } \\
\text { heavy }\end{array}$ & 47 & 64,4 \\
\hline & Light & 26 & 35,6 \\
\hline & Total & 73 & 100 \\
\hline
\end{tabular}

Table 2

Distribution of Frequency Description of Nutrition Status on Street Children at RPA Gank in Bandung city 2017

\begin{tabular}{clccc}
\hline No. & & Nutrition status & frekuensi & Persentase \\
\hline 1 & thin & & 32 & 43,8 \\
2 & Normal & & 35 & 47,9 \\
3 & fat & & 6 & 8,2 \\
\hline & & Total & $\mathbf{7 3}$ & $\mathbf{1 0 0}$ \\
\hline
\end{tabular}

Table 3

Corelation Lifestyle with Nutrition Status in Street Children at RPA Gank in Bandung city 2017

\begin{tabular}{|c|c|c|c|c|c|c|c|c|c|}
\hline \multirow{3}{*}{ Lifestyle } & \multicolumn{6}{|c|}{ Nutrition status } & \multirow{2}{*}{\multicolumn{2}{|c|}{ Total }} & \multirow{3}{*}{ p-value } \\
\hline & \multicolumn{2}{|c|}{ Kurus } & \multicolumn{2}{|c|}{ Normal } & \multicolumn{2}{|c|}{ Gemuk } & & & \\
\hline & $\mathbf{f}$ & $\%$ & $\mathbf{f}$ & $\%$ & f & $\%$ & $\mathbf{f}$ & $\%$ & \\
\hline \multicolumn{10}{|l|}{ Sleeps habits } \\
\hline$<6$ hour/day & 32 & 49,2 & 27 & 41,5 & 6 & 9,2 & 65 & 100 & \multirow{3}{*}{0,045} \\
\hline 6-8 hour/day & 0 & 0 & 7 & 100 & 0 & 0 & 7 & 100 & \\
\hline$>8$ hour/day & 0 & 0 & 1 & 100 & 0 & 0 & 1 & 100 & \\
\hline Diet & & & & & & & & & 0,000 \\
\hline$<3$ times/day & 31 & 66 & 13 & 27,7 & 3 & 6,4 & 47 & 100 & \\
\hline$\geq 3$ times/day & 1 & 3,8 & 22 & 84,6 & 3 & 11,5 & 26 & 100 & \\
\hline
\end{tabular}




\begin{tabular}{lccccccccc}
\hline smooking & 32 & 44,4 & 35 & 48,6 & 5 & 6,9 & 72 & 100 & 0,003 \\
Yes & 0 & 0 & 0 & 0 & 1 & 1 & 1 & 100 & \\
No & & & & & & & & & \\
\hline Smell the glue & 16 & 76,2 & 4 & 19,0 & 1 & 4,8 & 21 & 100 & 0,002 \\
Smell the glue & 16 & 30,8 & 31 & 59,6 & 5 & 9,6 & 52 & 100 & \\
No Smell the glue & & & & & & & & & \\
\hline Drinking alcohol & 15 & 75,0 & 4 & 20,0 & 1 & 5,0 & 20 & 100 & 0,004 \\
yes & 17 & 32,1 & 31 & 58,5 & 5 & 9,4 & 53 & 100 & \\
no & & & & & & & & & \\
\hline Drug use & 6 & 83,3 & 1 & 16,7 & 0 & 0 & 6 & 100 & 0,023 \\
yes & 27 & 40,3 & 34 & 50,7 & 6 & 9,0 & 67 & 100 & \\
no & & & & & & & & & \\
\hline Sexual behavior & 21 & 44,7 & 23 & 48,9 & 3 & 6,4 & 47 & 100 & 0,745 \\
heavy & 11 & 42,3 & 12 & 46,2 & 3 & 11,5 & 26 & 100 & \\
light & & & & & & & & \\
\hline
\end{tabular}

Table 4

Selection of Multivariate Candidate Variables

\begin{tabular}{clccc}
\hline No & \multicolumn{1}{c}{ lifestyle } & p-value & OR & 95\% CI \\
\hline 1 & Sleep habits & 0,998 & 0.538 & $0,197-0,773$ \\
2 & diet & 0,000 & 48,437 & $6,004-390,773$ \\
3 & smooking & 0,998 & 0.714 & $0,635-0,803$ \\
4 & Kebiasaan smell the glue & 0,001 & 0,139 & $0,053-0,362$ \\
5 & Dringking alcohol & 0,002 & 0,157 & $0,049-0,505$ \\
6 & Drug use & 0,075 & 0,135 & $0,015-1,221$ \\
7 & Sexual behavior & 0,745 & 0,147 & $0,011-1,652$ \\
\hline
\end{tabular}

Table 5

Results of Mutivariate Analysis between Diet, Smell the glue, Drinking Alcohol, Drug Use with Nutritional Status In Street Children In RPA Gank

City of Bandung Year 2017

\begin{tabular}{llccccc}
\hline No & lifestyle & p-value & OR Ada & $\mathbf{9 5 \%}$ CI & $\begin{array}{c}\text { OR Tidak } \\
\text { Ada }\end{array}$ & 95\% CI \\
\hline 1 & diet & 0,000 & 25,095 & $3,546-177,591$ & 15,518 & $44,405-126,663$ \\
2 & Smell the glue & 0,001 & 0,295 & $0,173-0,506$ & 2,127 & $1,295-3,494$ \\
3 & Drinking alcohol & 0,002 & 0,318 & $0,187-0,543$ & 2,022 & $1,238-3,303$ \\
4 & Drug use & 0,075 & 0,353 & $0,200-0,625$ & 2,617 & $0,807-8,486$ \\
\hline
\end{tabular}

\section{DISCUSSION}

The results showed that most street children rested sleep $<6$ hours / day. Lack of sleep due to the habits of street children to always stay up staying with friends. This result is in accordance with research conducted by Muthia about sleep disorder disorder in adolescence got result that adolescent tends to have trouble sleep pattern that sleep less than 6 hour [9].

The result showed that street children diet $(64,4 \%)$ more than half of $<3$ times / day. This is because the activities of other street children that can affect the diet such as smoking habits that cause lazy to eat. 
The result showed that most of street children in RPA Gank Kota Bandung smoke $(98,6 \%)$. Habit is because smoking has become commonplace in the community, especially on street children. This result is consistent with Tri Sulati's research on the dynamics of smoking behavior in adolescents which shows that teenage smoking experiences almost entirely because of the surroundings for various reasons such as prestige within a group and appear to be more mature [10].

The results showed that not all street children do smell the glue, but about 21 people $(28.8 \%)$ do smell the glue. These habits arise when the socialization of the environment is less good.'This is in accordance with the research Siti Chomariah on the behavior of sucking glue on teenagers found the result that the habit smell the glue because of the imperfect socialization agency either from family or play group [11]

Various kinds of alcoholic beverages and can still be bought free but limited in the community environment so for the neighborhood street children, drinking alcohol can be one of the habits. This is in accordance with the results of research showing that less than half of alcohol drinking (27.4\%) as many as 20 people.

The results showed that most street children in RPA Gank Bandung City do not use drugs. But there are still using drugs as much as $8.2 \%$. And did not rule out the answers of respondents feared if answering as a drug user because now the use of drugs is prohibited.

Overview of Nutrition Status on Street Children in RPA Gank in Bandung city showed normal nutritional status as much as $47.9 \%$ and obese as many as 6 people. This shows that the rest there are street children who have less nutritional status. Nutritional status is less can be experienced by street children because of the many factors that affect. The results showed that there is a significant relationship between sleeping habits with nutritional status in street children in RPA Gank Bandung. This is because the habit of lack of sleep and stay up that causes street children lazy to eat. The results showed that there is a significant relationship between diet with nutritional status in street children in RPA Gank Bandung. With eating habits that lack of eating certainly lack nutritional status. This result is in accordance with research conducted by Nur'aini regarding the pattern of activity, food consumption and nutritional status of street children in Bandung resulted that the lack of nutrient intake in street children cause the average nutritional status of street children is less [12].

The results showed that there is a significant relationship between smoking habits with nutritional status in street children in RPA Gank Bandung. These results are consistent with Iftita's research on lifestyle relationships with juvenile nutritional status with the result that lifestyle smoking habits have a relationship with juvenile nutritional 
status [13]. The results showed that there is a significant relationship between smell the glue habits with nutritional status in street children in RPA Gank Kota Bandung. This result is in accordance with research conducted by Azriful on the description of inhalation drug use (smell the glue) on street children in Makassar city resulted that the habits of children who smell the glue will affect the lack of nutrition because adolescents will be lazy to eat [14]. The results showed that there was a significant relationship between drinking alcohol consumption and nutritional status in street children in RPA.

\section{CONCLUSION}

Conclusions in this study are sleep habits most $<6$ hours / day, eating more than half of $<3$ times / day, smoking habit most smoking, the habit of smell the glue more than half do not smell the glue, drinking alcohol more than half do not drink alcohol and the use of drugs mostly do not use drugs, nutritional status less than half of normal, there is a significant relationship between sleeping habits with nutritional status in street children in RPA Gank Bandung with p-value 0.045 , there is a significant relationship between diet with nutritional status on street children in RPA Gank Kota Bandung with pvalue 0,000 , there is a significant relationship between smoking habit with nutritional status in street children in RPA Gank Bandung with p-value 0.003, there is a significant relationship between smell the glue habits with nutritional status in street children in RPA Gank Kota Bandung with p-value 0,002, there is significant relation between a habit of drinking alcohol with nutritional status on street children in RPA Gank Bandung with pvalue 0.004 , there is a significant relationship between the use of drugs with nutritional status in street children in RPA Gank Bandung with $\mathrm{p}$-value 0.023 , there is no relationship between behavior sexual with nutritional status on street children in RPA Gank Bandung with p-value 0.745, subvariabel lifestyle that has the highest effect on nutritional status in sequence that is diet, drinking habit, smell the glue habit and drug use and the highest influence that is pattern eating with an OR value of 25,095 times.

\section{REFERENCES}

[1]. Suyatno. 2010. Penyebab Anak Menjadi Anak Jalanan. Yogjakarta: Universitas Diponegoro.

[2]. Al-Affiat. 2012. Perilaku Anak Jalanan. Jakarta: EGC.

[3]. Walgito, B. 2010. Pengantar Psikologi Umum. Yogyakarta: Penerbit Andi

[4]. Mahmudiono. 2010. Hubungan Pola Makan, Aktivitas Fisik, Sikap, Dan Pengetahuan Tentang Obesitas Dengan Status. Bandung: Rineka Cipta

[5]. Hardinsyah. 2012. Kecukupan Energi, Lemak, Proein dan Karbohidrat. Bogor: Tunas Muda

[6]. Dinas Sosial Kota Bandung. 2015. Jumlah Anak Jalanan di Kota Bandung. Bandung. Dinas Sosial Kota Bandung. [7]. Marmi. 2013. Gizi Dalam Kesehatan Reproduksi. Yogyakarta: Pustaka Pelajar. 
[8]. Sofyan. 2014. Dasar-Dasar Metodologi Penelitian Klinis. Jakarta: Binarupa Aksara [9]. Effendi. 2016. Dasar-Dasar Keperawatan Kesehatan Masyarakat. Yogyakarta: Nuha Medika

[10]. Kemenkes RI. 2013. Profil Kesehatan Indonesia. Jakarta: Kemenkes RI.

[11]. Persagi. 2010. Komposisi Makanan Sehat. Jakarta: Persatuan Ahli Gizi Indonesia (PERSAGI).

[12]. Widianti. 2013. Hubungan Antara Body Image dan Perilaku Makan dengan Status Gizi Remaja Putri di SMA Theresiana. Jurnal FKUI

[13]. Supariasa. 2012. Pendidikan Dan Konsultasi Gizi. Jakarta : EGC

[14]. Soetjiningsih. 2010. Tumbuh Kembang Anak. Jakarta: Buku Kedokteran EGC.

[15]. Syahputra. 2013. Penilaian Status Gizi. Jakarta : EGC

[16]. Riyadi. 2009. Penilaian Status Gizi Dalam Pengantar Pangan dan Gizi. Penebar Swadaya. Jakarta.

[17]. Tarwotjo. 2012. Dasar-Dasar Ilmu Gizi. Grasindo. Jakarta.
[18]. Arikunto, Suharsimi. 2002. Prosedur Penelitian: Suatu Pendekatan Praktek. Edisi Revisi. Jakarta: PT. Rineka Karya.

[19]. Notoatmodjo, S. 2010. Promosi Kesehatan Teori dan Aplikasi. Jakarta: PT Rineka Cipta

[20]. Sopiyudin. 2010. Statistik Untuk Kedoteran dan Kesehatan. Jakarta: Salemba Media.

[21]. Nursalam. 2010. Asuhan Keperawatan Bayi dan Anak (Untuk Perawat dan Bidan) Edisi 1. Jakarta: Salemba Medika.

[22]. Muthia. 2014. Hubungan Kebiasaan Merokok Remaja Dengan Gangguan Pola Tidur. Jurnal Program Profesi Ners Universitas Riau

[23]. Eni Purwani. 2013. Pola Makan dan Status Gizi Anak Jalanan di Sekitar Kampus Universitas Muhammadiyah Surakarta. Jurnal Program Studi Gizi Fakultas Ilmu Kedokteran Universitas Muhammadiyah Surakarta.

[24]. Tri Sulati. 2015. Dinamika Perilaku Merokok Pada Remaja. Tesis Program Magister Psikologi Sekolah Pascasarjana Universitas Muhammadiyah Surakarta. 